\title{
Good Governance, Sistem Pengendalian Intern, Konflik Kerja dan Kinerja Pemerintah dengan Motivasi Kerja sebagai Pemoderasi
}

\author{
Gede Ananda Krista Yuda ${ }^{*}$ \\ Ni Putu Sri Harta Mimba ${ }^{2}$ \\ 1,2Fakultas Ekonomi dan Bisnis Universitas Udayana, Indonesia \\ ${ }^{*}$ Correspondences : kristayuda21@gmail.com
}

\begin{abstract}
ABSTRAK
Tujuan penelitian adalah menguji pengaruh Good Governance, sistem pengendalian intern (SPI), konflik kerja dan kinerja pemerintah dengan motivasi kerja sebagai variabel moderasi. Penelitian dilakukan di OPD (Organisasi Perangkat Daerah) di Kabupaten Klungkung dengan sampel berjumlah 150 orang. Data dikumpulkan dengan penyebaran kuesioner dan teknik analisis dalam penelitian adalah Moderated Regression Analysis (MRA). Hasil penelitian menunjukan Good Governance berpengaruh negatif sedangkan SPI berpengaruh positif terhadap kinerja pemerintahan. Konflik kerja tidak berpengaruh terhadap kinerja. Motivasi kerja mampu memperkuat pengaruh Good Governance terhadap kinerja Motivasi kerja belum mampu memperkuat pengaruh sistem pengendalian intern dan konflik kerja terhadap kinerja pemerintahan. Jadi motivasi kerja belum memoderasi pengaruh variabel sistem pengendalian intern dan konflik kerja terhadap kinerja pemerintahan.
\end{abstract}

Kata Kunci: Good Governance; Sistem Pengendalian Intern; Konflik Kerja; Motivasi; Kinerja.

\section{Good Governance, Internal Control System, Work Conflict and Government Performance with Work Motivation as Moderating}

\section{ABSTRACT}

The purpose of this research is to examine the effect of Good Governance, internal control system (SPI), work conflict and government performance with work motivation as a moderating variable. The study was conducted at the OPD (Regional Apparatus Organization) in Klungkung Regency with a sample of 150 people. Data was collected by distributing questionnaires and the analysis technique in this study was Moderated Regression Analysis (MRA). The results showed that Good Governance had a negative effect, while SPI had a positive effect on government performance. Work conflict has no effect on performance. Work motivation is able to strengthen the influence of Good Governance on performance. Work motivation has not been able to strengthen the influence of the internal control system and work conflict on government performance. So work motivation has not moderated the effect of internal control system variables and work conflict on government performance.

Keywords: Good Governance; Internal Control Systems; Work Conflicts; Motivation; Performance.

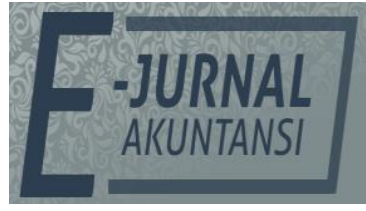

e-ISSN 2302-8556

Vol. 32 No. 1

Denpasar, Januari 2022

Hal. 124-138

DOI:

10.24843/EJA.2022.v32.i01.p09

PENGUTIPAN:

Yuda, G. A. K. \& Mimba, N. P. S. H. (2022). Good

Governance, Sistem

Pengendalian Intern, Konflik

Kerja dan Kinerja Pemerintah dengan Motivasi Kerja sebagai Pemoderasi. E-Jurnal Akuntansi, 32(1), 124-138

RIWAYAT ARTIKEL: Artikel Masuk: 12 April 2021 Artikel Diterima: 25 Mei 2021

Artikel dapat diakses : https://ojs.unud.ac.id/index.php/Akuntansi/index 


\section{PENDAHULUAN}

Kabupaten Klungkung masih memiliki persoalan yang cukup banyak. Hal tersebut bisa dilihat terutama terkait dengan upaya peningkatan baik dari sisi Indeks Pembangunan Manusia, Pertumbuhan Ekonomi, Nilai Akuntabilitas Kinerja serta Realisasi Anggaran. IPM Kabupaten Klungkung pada tahun 2019 hanya berada di angka indeks 71,71, masih tertinggal dibandingkan IPM Provinsi, Bali yang nilai indeksnya 75,38. Selain itu, IPM Kabupaten klungkung pada tahun itu juga menempati urutan ke tujuh dari sembilan Kabupaten/Kota di Provinsi Bali. Pertumbuhan Ekonomi Kabupaten Klungkung juga mengalami peristiwa stagnansi juga merupakan permasalahan tersendiri yang berdampak pada pembangunan daerah bagi Kabupaten Klungkung. Pada tahun 2017 ke tahun 2018, pertumbuhan ekonomi Kabupaten Klungkung memang mengalami peningkatan tetapi masih lebih rendah dari pertumbuhan ekonomi Provinsi Bali, meski lebih tinggi dari pertumbuhan ekonomi nasional.

Selain itu, terbaru tahun 2019 menunjukkan fakta yakni Laju Pertumbuhan Ekonomi dari Kabupaten Klungkung merupakan yang terakhir diantara Kabupaten/Kota di Bali. Mengenai Nilai Akuntabilitas Kinerja Kabupaten Klungkung, pada tahun 2019, realisasinya masih gagal mencapai target. Pada tahun 2019, AKIP setelah dievaluasi menunjukkan bahwa realisasi yang tercapai adalah sebesar 65,53, kurang dari target sebesar 66,00 poin. Meski Nilai Akuntabilitas Kinerja di Kabupaten Klungkung memiliki kecenderungan meningkat, tetapi diakui bahwa hasil evaluasi AKIP memiliki kecenderungan penurunan pertumbuhan AKIP pada periode 2017-2019 dibanding periode 20142017 dimana total peningkatan nilai AKIP pada 2014-2017 sebesar 21,62 sedangkan pada periode 2017-2019 hanya sebesar 2,81. Selain itu, kabupaten Klungkung masih menepati posisi 7 dari 9 kabupaten/kota yang ada di Bali. Realisasi anggaran Kabupaten Klungkung dapat dibagi menjadi dua segmen yakni segmen pendapatan dan segmen belanja. Realisasi pendapatan tercapai sebesar 98,14 persen atau meleset 23 miliar rupiah dari target. Pendapatan Asli Daerah tercapai sebesar 99,53 persen atau kurang sebesar 1,1 miliar rupiah dari target. Dana Perimbangan tercapai sebesar 97,62 persen atau berselisih sebesar 16,9 miliar rupiah dari yang direncanakan serta Pendapatan Lain-Lain tercapai sebesar 98,32 persen atau kurang dari yang direncanakan sebesar 5,1 miliar. Mengenai penganggaran belanja, ternyata bahwa belanja langsung Pemerintah Klungkung masih memegang porsi belanja yang kurang signifikan dari belanja tidak langsung. Belanja Langsung memegang porsi 45 persen dan Belanja Tidak Langsung menghabiskan sebesar 55 persen. Belanja tidak langsung merupakan belanja yang dilaksanakan pemerintah dimana tidak memiliki korelasi langsung dengan pelaksanaan program dan kegiatan yang direncanakan (Contohnya: Belanja Pegawai, Subsidi, Bantuan Sosial) sedangkan belanja langsung adalah belanja yang dilaksanakan pemerintah daerah yang berhubungan langsung dengan program yang direncanakan (Pemerintah Kabupaten Klungkung, 2020).

Suatu instansi pemerintahan yang baik tentu diukur dari bagaimana baik buruknya dampak dari kinerja yang telah dibuat terhadap keadaan masyarakat yang baik secara langsung maupun tidak langsung dinaunginya. Untuk itu, tentu diperlukan pegawai-pegawai berkinerja yang baik untuk memaksimalkan hal tersebut. Tetapi terkadang kualitas individu pegawai tidak cukup untuk 
menunjang kinerja organisasi keseluruhan. Suasana dalam instansi/organisasi secara keseluruhan pastinya mempengaruhi maksimal atau tidaknya kinerja dari pegawai dalam organisasi.

Pada akhir-akhir, sering didengungkan mengenai tata kelola manajemen yang baik atau Good Governance dalam menjalankan aktivitas pemerintahan. Good Governance adalah bentuk dari penerimaan atas pentingnya perangkat aturan atau tata pengelolaan yang baik dalam kaitannya dengan relasi, fungsi dan kepentingan atas pihak terkait dalam bisnis ataupun pemerintahan (Hokayem \& Kairouz, 2014). FCGI menjelaskan dengan melaksanakan Good Governance, maka hal yang didapatkan organisasi biasanya adalah peningkatan kinerja dengan pengambilan keputusan serta peningkatan pelayanan publik (Putra \& Putra, 2018).

Sistem pengendalian intern adalah suatu sistem yang didesain untuk memberikan suatu kepastian bahwa tujuan organisasi mampu diraih dengan pelaksanaan program yang efektif dan efisien (Naz'aina, 2015). Pemerintah dalam hal ini perlu untuk melaksanakan sebuah sistem pengendalian intern yang sangat bermanfaat untuk meningkatkan transparansi dan akuntabilitas dalam pelaksanaan kerja yang berujung pada perbaikan kualitas kinerja. Sistem pengendalian internal yang baik akan bermanfaat bagi organisasi dalam mencegah terjadinya penganggaran yang buruk serta membantu organisasi untuk bekerja secara efektif dan harmonis sekaligus mendeteksi kesalahan dan penyimpangan dalam operasinya (Aziz et al., 2015). Jika sistem pengendalian intern tidak atau gagal dilaksanakan, maka akan timbul ketidakefektifan kerja pemerintahan yang berdampak pada pemborosan anggaran (Yurniwati \& Rizaldi, 2015). Pada intinya, menerapkan sistem yang tepat akan membantu operasi organisasi menjadi lebih efektif dan efisien (Sanusi et al., 2015).

Dalam melaksanakan pekerjaan, terkadang terjadi konflik kerja yang dapat disebabkan dikarenakan kesalahan dalam komunikasi, pemberian beban kerja yang terlalu berlebihan, atau keadaan yang tidak menyenangkan yang dihadapi. Menurut Mangkunegara, konflik kerja merupakan keadaan atas adanya perselisihan diantara anggota organisasi atas perbedaan tujuan, status serta perbedaan persepsi. Dari penjelasan-penjelasan tersebut, dapat disebutkan bahwa konflik kerja dapat terjadi jika terdapat perbedaan diantara dua orang atau lebih misalnya perbedaanpersepsi, persaingan, pengetahuan, tujuan, dan perbedaan lainnya yang terjadi antar individu (Fatikhin et al., 2017).

Selain ketiga variabel tersebut, ada faktor-faktor lainnya yang kemungkinan menjadi penyebab baik tidaknya kinerja pegawai yakni motivasi kerja. Luthan dalam jurnal (Khoshnevis \& Tahmasebi, 2016) menyatakan bahwa motivasi adalah proses yang dimulai dengan kekurangan atau kebutuhan fisiologis yang mampu menimbulkan perilaku atau dorongan untuk meraih tujuan yang hendak diraih. Motivasi dapat terdiri dari motivasi intrinsik dan ekstrinsik. Selain itu, motivasi menurut Mangkunegara dalam jurnal Julianry et al (2017) merupakan dorongan yang muncul dalam diri seseorang baik karena faktor internal maupun eksternal yang menggerakannya untuk melakukan sesuatu demi mencapai tujuan. Motivasi Gagné dan Deci dalam penelitian Kolk et al (2019) mendefinisikan motivasi intrinsik merupakan motivasi yang dimana individu melaksanakan kegiatan yang bersangkutan karena kegiatan tersebut menarik 
ketertarikat tersendiri dari individu tersebut dan motivasi ekstrinsik sebaliknya merupakan hal-hal diluar individu tersebut yang mampu meningkatkan semangat dalam melaksanakan aktivitas seperti penghargaan nyata atau verbal sehingga kepuasan tidak datang dari aktivitas itu sendiri. Maka daripada itu, kinerja individu anggota organisasi juga bergantung pada kepuasan mereka dengan penghargaan ekstrinsik (Ciobanu \& Androniceanu, 2015). Dalam penelitian ini, motivasi adalah variabel moderasi. Hal ini dikarenakan diyakini jika seluruh pelaksanaan kegiatan yang didorong serta dilandasi oleh motivasi yang kuat untuk meraih tujuan, maka hasil dari kegiatan tersebut akan maksimal serta memuaskan. Pegawai yang bermotivasi tinggi tampaknya mengembangkan sikap dan perilaku terkait pekerjaan yang positif seperti misalnya, mereka menunjukkan tingkat komitmen organisasi yang lebih tinggi, mereka percaya bahwa pekerjaan mereka penting, dan keyakinan ini mengarahkan mereka untuk bekerja lebih keras, maka daripada itu, motivasi menjadi fokus yang penting juga dari para administrator karena tingkat kinerja akan memburuk jika tingkat motivasi pegawai turun (Chatzopoulou et al., 2015). Hal tersebut juga ditegaskan oleh Taghipour \& Dejban (2013) dalam jurnalnya dimana motivasi anggota organisasi merupakan salah satu strategi petinggi organisasi untuk meningkatkan prestasi kerja yang efektif di antara anggota dalam organisasi.

Teori keagenan merupakan teori yang mampu menjelaskan hubungan kontraktual antar pihak, dimana disatu sisi dapat disebut sebagai agen dan pihak lainnya adalah principal (Widasari \& Putri, 2018). Eisenhardt menjelaskan bahwa agen merupakan pihak yang menerima pendelegasian tugas oleh prinsipal, sedangkan prinsipal adalah pemilik. Hubungan keagenan pada instansi pemerintah yaitu agen merupakan pihak yang mengambil keputusan dan pihak yang terlibat dalam pengelolaan yang berkaitan dengan organisasi atas nama pemilik (Purwanto et al., 2015).

Teori keagenan mengungkapkan yakni Good Governance adalah cara pengelolaan dengan efektif serta efisien dalam kaitannya dengan meraih tujuan orgamisasi. Pemerintah yang telah melaksanakan prinsip-prinsip Good Governance diharapkan agar mampu melaksanakan tugas serta penyelenggaraan pemerintahan dengan baik (Putra \& Putra, 2018). Selain itu, dalam teori keagenan juga disebutkan bahwa dalam organisasi terdapat biaya keagenan yakni anggaran untuk mengarahkan perilaku dari agen. Salah satu dari biaya keagenan tersebut adalah melaksanakan sebuah sistem pengendalian intern (Zogning, 2017).

Motivasi seorang anggota organisasi sangat dipengaruhi oleh berbagai dorongan yang dimana tercantum dalam Teori ERG (Existence, Relatedness, and Growth). Teori ini adalah penyempurnaan oleh Alderfer dari teori kebutuhan yang dikemukakan oleh Maslow. Sebelumnya, Maslow menyebutkan dalam teori kebutuhan hierakis bahwa hierakis kebutuhan terdiri dari 5 level, yakni kebutuhan psikologis, keamanan, sosial, ego, dan aktualisasi diri (Lee \& Raschke, 2016). Menurut Alderfer, ada tiga hieraki dalam kebutuhan inti yaitu eksistensi (existence), kekerabatan atau berhubungan (relatedness), dan pertumbuhan (growth). Kebutuhan eksistensi adalah kebutuhan berupa kebutuhan-kebutuhan dasar seperti gaji, kondisi kerja, peralatan kerja atau kebutuhan mendasar manusia untuk bertahan hidup dan sebagainya. Kebutuhan yang kedua adalah kebutuhan berhubungan yakni keinginan individu untuk menjaga relasi yang bermanfaat. 
Hasrat sosial dan status menuntut interaksi dengan orang-orang lain agar dipuaskan. Kebutuhan yang ketiga adalah kebutuhan pertumbuhan merupakan keinginan dalam diri untuk mengembangkan kualitas diri, mencakup komponen instriksi dari kategori penghargaan Maslow dan karakteristik-karakteristik yang tercakup pada aktualisasi diri (Mayvita et al., 2017).

Penelitian dari Azlina \& Amelia (2014) mengenai pengaruh Good Governance terhadap kinerja pemerintah daerah Pelalawan menunjukkan bahwa Good Governance terbukti berpengaruh positif signifikan terhadap kinerja pemerintahan daerah tersebut. Penelitian lainnya yang dilakukan oleh Yudhasena \& Putri (2019) dalam Pengaruh Good Government Governance Terhadap Kinerja Organisasi Perangkat Daerah (OPD), menunjukkan hal sama, bahwa Good Governance memiliki efek langsung terhadap kinerja organisasi.

Berdasarkan logika berpikir, jika sebuah organisasi atau dalam hal ini pemerintah, melaksanakan berbagai unsur-unsur Good Governance seperti keterbukaan, peningkatan efisiensi di segala bidang, kejelasan tanggung jawab dan kewajaran pengelolaan pemerintahan, seharusnya kegiatan pemerintahan menghasilkan kinerja yang lebih baik daripada pemerintahan yang melalaikan pelaksanaan Good Governance dikarenakan dengan pelaksanaan Good Governance, permasalahan seperti inefisiensi budget, keterlambatan realisasi program, melesetnya target kerja, dll tidak dialami oleh pemerintahan.Dari teori berkaitan dengan Good Governance, penelitian-penelitian terdahulu, serta logika berpikir peneliti, maka dibuatlah hipotesis yakni sebagai berikut.

$\mathrm{H}_{1}$ : Good Governance berpengaruh positif pada Kinerja Pemerintah Daerah Kabupaten Klungkung

Hasil-hasil penelitian terkait pengaruh sistem pengendalian intern terhadap kinerja seperti yang dilakukan Ilias et al (2016) yang berjudul Management Control System and Performance: Accountability Attributes in Local Authorities dimana hasilnya menyatakan bahwa variabel sistem pengendalian internal terbukti memberi dampak positif terhadap kinerja pemerintahan. Penelitian dari Putra \& Putra (2018) yang berjudul "Pengaruh Good Governance dan Sistem Pengendalian Intern Pemerintah pada Kinerja Pemerintah Daerah" juga memberikan hasil yang sama terkait dampak adanya sistem pengendalian intern terhadap kinerja pegawai pemerintahan.

Sistem Pengendalian Intern terbukti dalam kebanyakan kasus terbukti mampu meningkatkan kinerja. Hal ini bisa terjadi dikarenakan dengan adanya sistem pengendalian intern, akan adanya pengawasan serta pemantauan atas baik proses serta hasil kinerja sehingga mampu mengetahui dan menganalisis masalahmasalah kerja pemerintahan yang nantinya ditemukan solusi serta masukanmasukan untuk perbaikan kinerja. Hipotesis yang dibangun dari kajian pustaka, hasil penelitian yang sudah pernah dilakukan ditambah logika berpikir peneliti adalah sebagai berikut.

$\mathrm{H}_{2}$ : Sistem Pengendalian Intern berpengaruh positif pada Kinerja Pemerintah

Daerah Kabupaten Klungkung.

Penelitian yang dilakukan oleh Endila \& Syamsir (2017) mengenai Pengaruh Konflik Kerja Terhadap Kinerja Perangkat Nagari Dalam Pengelolaan Keuangan Nagari Di Kabupaten 50 Kota menunjukkan bahwa konflik kerja memiliki pengaruh signifikan terhadap kinerja. 
Konflik kerja memang telah menjadi keseharian dari jalannya setiap proses kerja berorganisasi. Hal itu juga tidak luput dari proses kegiatan sehari-hari pemerintah. Konflik kerja dapat menimbulkan perpecahan atau justru menjadi pemicu semangat kerja. Konflik kerja yang berdampak negatif justru sering kali cenderung berbahaya karena mampu menghadirkan ketegangan antar anggota serta kadang-kadang menghasilkan keengganan bekerja sama yang berdampak pada terbengkalainya perkembangan program kerja. Berbeda halnya jika konflik kerja memunculkan dampak positif, hal yang terjadi yakni masing-masing anggota akan bersaing secara sehat dan bekerja lebih keras demi mencapai hasil yang diinginkan seperti peningkatan gaji, promosi jabatan, maupun pengakuan. Konflik kerja yang seperti ini justru dilestarikan demi menjaga kompetitifnya kinerja pemerintahan. Maka, menurut peneliti, pemerintah bisa mendapatkan manfaat dari aspek konflik kerja dengan tentunya diperlukan pengendalian demi menghindari efek negatif dari konflik kerja. Dari hal tersebut, maka hipotesis yang diambil dari pengaruh variabel ini terhadap kinerja adalah sebagai berikut.

$\mathrm{H}_{3}$ : Konflik Kinerja berpengaruh positif pada Kinerja Pemerintah Daerah Kabupaten Klungkung.

Penelitian terdahulu baik dari Ruhanda (2018) yang berjudul Pengaruh Kompensasi dan Penerapan Good Corporate Governance Terhadap Kinerja Pegawai dengan Motivasi Kerja sebagai Variabel Intervening pada Palang Merah Indonesia Kota Bandung, Wijaya et al (2016) berjudul Analisis Pengaruh Independensi, Motivasi, Pengalaman Kerja, Profesionalisme, Dan Gaya Kepemimpinan Terhadap Efektivitas Penerapan Sistem Pengendalian Intern dan Valentina et al (2020) berjudul Pengaruh Burnout dan Konflik Kerja Terhadap Kinerja dengan Motivasi Kerja Sebagai Variabel Moderasi pada Perawat RSUD Dr Moewardi Surakarta dimana hasilnya mengungkapkan bahwa motivasi mampu memperkuat pengaruh ketiga variabel independen tersebut terhadap kinerja karyawan.

Motivasi kerja mendorong pribadi antar anggota organisasi untuk berusaha mencapai target yang dituju. Pelaksanaan Good Governance, sistem pengendalian intern, dan adanya sedikit gesekan antar anggota (konflik kerja) yang positif terutama terkait target yang sama-sama secara individu ingin dicapai (seperti kenaikan gaji atau pengakuan) memang mampu meningkatkan kinerja. Tetapi jika kesemua tindakan tersebut dibarengi dengan motivasi kerja yang lemah, maka dipastikan kinerja menjadi tidak maksimal atas kurangnya dorongan pribadi, ambisi, serta kurang percaya diri menghadapi problematika permasalahan kerja dalam pemerintahan. Diyakini dengan munculnya motivasi diri sebagai pemicu semangat kerja, segala pelaksanaan Good Governance, sistem pengendalian intern, dan tanggapan terhadap terhadap konflik kerja menjadi lebih baik. Maka daripada itu, hipotesis yang diangkat adalah sebagai berikut.

$\mathrm{H}_{4 a}$ : Motivasi Kerja memperkuat pengaruh Good Governance, sistem pengendalian kerja, dan konflik kerja pada Kinerja Pemerintah Daerah Kabupaten Klungkung. 


\section{METODE PENELITIAN}

Good Governance diukur dari tingkat unsur-unsur transparency, fairness, responsibility dan accountability (Azlina \& Amelia, 2014). Sistem Pengendalian Intern sendiri diukur dari unsur-unsur seperti lingkungan pengendalian, penafsiran resiko, sistem informasi dan komunikasi, aktivitas pengendalian dan pemantauan (Afiah \& Azwari, 2015). Konflik Kerja diukur dari konflik kerja fungsional dan konflik kerja disfungsional (Yofandi, 2017). Motivasi diukur dari unsur-unsur yang diantaranya tanggung jawab, penghargaan, pekerjaan itu sendiri, pengembangan dan kemajuan, gaji, kebijakan, hubungan kerja, lingkungan kerja, dan supervise (Kolk et al., 2019). Kinerja diukur dari bagianbagian terkait kinerja seperti kualitas, kuantitas, ketepatan waktu, efektivitas, kemandirian dan komitmen kerja (Santosa et al., 2017).

Populasi dalam penelitian ini adalah anggota dari Organisasi Perangkat Daerah (OPD) yang ada di Kabupaten Klungkung dimana OPD tersebut tercantum berdasarkan Peraturan Daerah Kabupaten Klungkung Nomor 9 Tahun 2016 tentang Pembentukan dan Susunan Perangkat Daerah Kabupaten Klungkung. Pemilihan sampel dilakukan dengan menggunakan teknik sampling kuota dimana target keseluruhan 5 anggota per OPD. Metode pengumpulan data yang digunakan adalan metode kuesioner yang artinya pengumpulan data dilakukan dengan menyebarkan formulir-formulir yang berisi pertanyaanpertanyaan terkait penelitian yang dilakukan kepada sampel yang telah ditentukan. Variabel-variabel yang ada menggunakan skala Likert 5 poin dengan skala Sangat Tidak Setuju (STS) diberikan 1 (poin); Tidak Setuju (TS) diberikan poin (2); Netral (N) diberikan poin (3); Setuju (S) diberikan poin (4); Sangat Setuju (SS) diberikan poin (5).

Teknik analisis data yang digunakan adalah Moderated Regression Analysis (MRA). MRA adalah aplikasi khusus regresi berganda linier dimana dalam persamaannya regresinya mengandung unsur interaksi (perkalian dua atau lebih variabel independen). Moderated Regression Analysis (MRA) ditunjukkan oleh persamaan regresi berikut (Ghozali, 2016:219).

$Y=\alpha+\beta_{1} X_{1}+\beta_{2} X_{2}+\beta_{3} X_{3}+\beta_{4} X_{4}+\beta_{5} X_{1} X_{4}+\beta_{6} X_{2} X_{4}+\beta_{7} X_{3} X_{4}+\varepsilon$

Keterangan :

$$
\begin{array}{ll}
\mathrm{Y} & =\text { Kinerja Pemerintah Daerah } \\
\mathrm{X}_{1} & =\text { Good Governance } \\
\mathrm{X}_{2} & =\text { Sistem Pengendalian Intern } \\
\mathrm{X}_{3} & =\text { Konflik Kerja } \\
\mathrm{X}_{4} & =\text { Motivasi } \\
\mathrm{a} & =\text { Konstanta } \\
\beta & =\text { Koefisien variabel } \\
\varepsilon & =\text { Variabel pengganggu }
\end{array}
$$

\section{HASIL DAN PEMBAHASAN}

Peneliti telah menghimpun sebanyak 150 sampel dari seluruh OPD yang terdapat di Kabupaten Klungkung. Berikut analisis statistik deskriptif hasil penelitian. N pada Tabel 1 artinya jumlah kuesioner yang diolah datanya dalam penelitian. Adapun penjelasan dari data-data Tabel 1. Nilai minimun dari Good Governance adalah 20 artinya nilai terendah dari variabel Good Governance adalah 20. Nilai 
maksimal/tertinggi dari variabel Good Governance adalah 30. Mean/Rata-rata dari nilai Good Governance ialah 26,31 dan standar deviasinya adalah 2,436. Nilai minimun dari sistem pengendalian intern adalah 25. Nilai maksimal/tertinggi dari variabel sistem pengendalian intern adalah 35. Mean/Rata-rata dari nilai sistem pengendalian intern ialah 30,37 dan standar deviasinya adalah 2,760. Nilai minimun dari konflik kerja adalah 18. Nilai maksimal/tertinggi dari variabel konflik kerja adalah 40. Mean/Rata-rata dari nilai konflik kerja ialah 26,92 dan standar deviasinya adalah 4,677. Nilai minimun dari motivasi kerja adalah 26. Nilai maksimal/tertinggi dari variabel motivasi kerja adalah 40. Mean/Rata-rata dari nilai motivasi kerja ialah 33,83 dan standar deviasinya adalah 3,210. Nilai minimun dari kinerja adalah 19. Nilai maksimal/tertinggi dari variabel kinerja adalah 30. Mean/Rata-rata dari nilai kinerja ialah 25,22 dan standar deviasinya adalah 2,476.

Tabel 1. Hasil Statistik Deskriptif

\begin{tabular}{lccccc}
\hline & $N$ & Minimum & Maximum & Mean & Std. Deviation \\
\hline X1 & 150 & 20 & 30 & 26,31 & 2,436 \\
X2 & 150 & 25 & 35 & 30,37 & 2,760 \\
X3 & 150 & 18 & 40 & 26,91 & 4,677 \\
X4 & 150 & 26 & 40 & 33,83 & 3,210 \\
Y & 150 & 19 & 30 & 25,22 & 2,476 \\
Valid N (listwise) & 150 & & & &
\end{tabular}

Sumber: Data Penelitian, 2021

Pertanyaan yang dianggap valid adalah pertanyaan nilai pearson correlation terhadap skor total adalah $(r \geq 0,3)$ (Sugiyono, 2017:503). Dan setelah dilaksanakan penyebaran kuesioner terhadap pegawai pemerintahan dalam OPD Klungkung, seluruh buah pertanyaan kuesioner adalah valid dikarenakan memiliki nilai pearson correlation lebih dari 0,3 .

Uji reliabilitas data dilakukan dengan melihat nilai cronbach's alpha dimana jika $(r>0,6)$, maka pertanyaan pada masing-masing variabel penelitian tersebut dinyatakan reliabel (Sugiyono, 2017:183). Dikarenakan seluruh pertanyaan variabel memiliki value cronbach's alpha $(r>0,6)$, maka pertanyaan pada masing-masing variabel penelitian tersebut dinyatakan reliabel.

Tabel 2. Uji Normalitas

\begin{tabular}{|c|c|c|c|c|c|}
\hline \multirow[b]{2}{*}{ Model } & \multirow{2}{*}{$\begin{array}{c}\text { Normalitas } \\
\text { Exact Sig. } \\
\text { (2-tailed) }\end{array}$} & \multirow[b]{2}{*}{ Variabel } & \multicolumn{2}{|c|}{ Multikolinearitas } & \multirow{2}{*}{$\begin{array}{c}\text { Heteroskedastisitas } \\
\text { Sig. }\end{array}$} \\
\hline & & & Tolerance & VIF & \\
\hline \multirow{4}{*}{1} & \multirow{4}{*}{0,084} & $\begin{array}{l}\text { Good Governance } \\
\text { (X1) }\end{array}$ & 0,373 & 2,684 & 0,383 \\
\hline & & $\begin{array}{c}\text { Sistem } \\
\text { Pengendalian } \\
\text { Intern (X2) }\end{array}$ & 0,343 & 2,918 & 0,436 \\
\hline & & $\begin{array}{c}\text { Konflik Kerja } \\
(\text { X3) }\end{array}$ & 0,892 & 1,122 & 0,829 \\
\hline & & $\begin{array}{c}\text { Motivasi Kerja } \\
(\mathrm{X} 4)\end{array}$ & 0,426 & 2,347 & 0,853 \\
\hline
\end{tabular}

Sumber: Data Penelitian, 2021

Uji normalitas berguna untuk menguji apakah dalam model regresi, variabel dependen maupun independen memiliki distribusi yang normal. Demi 
mengetahui distribusi data normal atau tidak, maka digunakan uji statistik nonparametrik Kolmogorov-Smirnov (K-S) dengan ketentuan jika probabilitasnya signifikan di atas 0,05, maka variabel tersebut terdistribusi secara normal (Ghozali, 2016:157). Dari hasil analisis yang telah dilaksanakan, seluruh distribusi data memiliki distribusi yang normal dimana probabilitasnya signifikannya adalah 0,084 yang lebih besar dari 0,05.

Uji multikolinearitas bertujuan untuk menguji apakah dalam model regresi terdapat korelasi antar variabel independen. Uji multikolinearitas dilakukan dengan melihat nilai tolerance atau variance inflation factor (VIF). Jika nilai tolerance $>0,1$ atau $\mathrm{VIF}<10$, maka dapat dikatakan model telah bebas dari masalah multikolinearitas (Ghozali, 2016:103). Dari hasil analisis yang telah dilaksanakan, seluruh variabel memiliki nilai tolerance $>0,1$ atau $\mathrm{VIF}<10$ yang artinya seluruh variable terbebas dari masalah multikoliniearitas.

Uji heteroskedastisitas bermanfaat menguji apakah dalam model regresi linear terjadi ketidaksamaan variance dari residual satu pengamatan ke pengamatan lainnya (Ghozali, 2016:134). Model regresi yang baik adalah yang homokedastisitas atau tidak terjadi heteroskedastisitas. jika nilai signifikansinya diatas tingkat kepercayaan 5\% maka dapat disimpulkan tidak mengandung adanya heteroskedastisitas (Ghozali, 2016:142). Dari hasil analisis ini, seluruh variable memiliki tingkat signifikansi diatas $5 \%$ atau 0,05 sehingga dapat disimpulkan tidak mengandung heteroskedastisitas. Berikut hasil dari uji Moderated Regression Analysis (MRA) setelah dilaksanakan pengujian.

Tabel 3. Hasil Uji Moderated Regression Analysis (MRA)

\begin{tabular}{cccccc}
\hline Model & \multicolumn{2}{c}{ Unstandardized Coefficients } & $\begin{array}{c}\text { Standardized } \\
\text { Coefficients }\end{array}$ & T & Sig. \\
\cline { 2 - 4 } & $\mathrm{B}$ & Std. Error & Beta & \\
\hline (Constant) & 61,800 & 18.002 & & 3,433 & 0,001 \\
X1 & $-3,414$ & 0,950 & $-3,357$ & $-3,592$ & 0,000 \\
X2 & 1,791 & 0,818 & 1,996 & 2,189 & 0,030 \\
X3 & $-0,298$ & 0,303 & $-0,562$ & $-0,982$ & 0,328 \\
X4 & $-1,478$ & 0,526 & $-1,916$ & $-2,810$ & 0,006 \\
X1X4 & 0,111 & 0,028 & 6,996 & 3,980 & 0,000 \\
X2X4 & $-0,049$ & 0,024 & $-3,539$ & $-2,032$ & 0,044 \\
X3X4 & 0,009 & 0,008 & 0,750 & 1,028 & 0,306 \\
\multicolumn{2}{c}{ Koefisien Determinasi: $0,636=63,6 \%$} & & F: 0,000 & \\
\hline
\end{tabular}

Sumber: Data Penelitian, 2021

Berdasarkan Tabel 3, dapat dijabarkan bahwa pada persamaan atau model MRA ini memiliki persamaan $\mathrm{Y}=61,800+(-3,414) \mathrm{X} 1+1,791 \mathrm{X} 2+(-0,298) \mathrm{X} 3+(-$ 1,478)X4 + 0,111X1X4 + (-0,049)X2X4 + 0,009X3X4 + ع1. Hal ini memiliki makna bahwa Konstanta Variabel Kinerja (Y) jika dimisalkan seluruh variablel independen bernilai konstan 0, maka nilai dari variable kinerja adalah 61,800. Konstanta Variabel Good Governance (X1) jika naik sebesar satu satuan, justru akan menurunkan sebesar 3,414 tingkat kinerja. Konstanta Variabel Sistem Pengendalian Intern (X2) jika naik sebesar satu satuan, maka akan memberikan kontribusi sebesar 1,791 terhadap peningkatan kinerja. Konstanta Variabel Konflik Kerja (X3) jika naik sebesar satu satuan, justru akan menurunkan sebesar sebesar 
0,298 tingkat kinerja. Konstanta Variabel Motivasi Kerja (X4) jika naik sebesar satu satuan, justru akan menurunkan sebesar sebesar 1,478 tingkat kinerja. Konstanta Variabel Good Governance yang dimoderasi oleh Motivasi Kerja (X1X4) jika naik sebesar satu satuan, maka akan memberikan kontribusi sebesar 0,111 terhadap peningkatan kinerja. Konstanta Variabel Sistem Pengendalian Intern yang dimoderasi oleh Motivasi Kerja (X2X4) jika naik sebesar satu satuan, justru akan menurunkan sebesar 0,049 tingkat kinerja. Konstanta Variabel Konflik Kerja yang dimoderasi oleh Motivasi Kerja (X3X4) jika naik sebesar satu satuan, maka akan memberikan kontribusi sebesar 0,009 terhadap peningkatan kinerja.

Nilai koefisien determinasi pada model penelitian ini adalah sebesar 0,636 yang memiliki makna bahwa model yang dilibatkan dalam penelitian ini mampu menjelaskan/mempengaruhi variabel dependen sebesar 63,6\%, sedangkan sisanya dipengaruhi variavel-variabel lain diluar penelitian. Terkait dengan uji $\mathrm{F}$ nya, model ini dikatakan layak karena memiliki nilai sig 0,000<0,05.

Sebuah hipotesis dinyatakan terbukti atau tidak dengan cara membandingkan tingkat signifikansi masing-masing variabel bebas $0,05(\alpha=5 \%)$. Apabila tingkat signifikansi dari $\mathrm{t}>\mathrm{a}$, maka Hipotesis ditolak, tetapi apabila tingkat signifikansi dari $\mathrm{t} \leq \mathrm{a}$, maka hipotesis terbukti. Dalam penelitian ini, terdapat 6 hipotesis yang hendak dibuktikan.

Berdasarkan Tabel 3, dalam persamaan, dapat dilihat bahwa nilai signifikansi dari variabel Good Governance adalah 0,000 yang artinya lebih kecil dari 0,05. Meski begitu, nilai konstanta dari variabel Good Governance ternyata adalah negatif yang dimana bertentangan dengan hipotesis bahwa Good Governance berpengaruh positif pada kinerja. Hal ini berarti bahwa H1 yakni hipotesis Good Governance berpengaruh positif terhadap kinerja pemerintahan ditolak. Mengenai H2, dapat dilihat bahwa nilai signifikansi dari variabel sistem pengendalian intern adalah 0,030 yang artinya lebih kecil dari 0,05. Nilai signifikansi tersebut membuktikan hipotesis bahwa Good Governance berpengaruh positif terhadap kinerja pemerintahan. Dalam pembuktian $\mathrm{H} 3$ dapat dilihat bahwa nilai signifikansi dari variabel konflik kerja adalah 0,328 yang artinya lebih besar dari 0,05. Nilai signifikansi tersebut berarti hipotesis bahwa konflik kerja berpengaruh positif terhadap kinerja pemerintahan ditolak. Untuk H4a dapat dilihat bahwa nilai signifikansi dari variabel motivasi kerja yang memoderasi Good Governance adalah 0,000 yang artinya lebih kecil dari 0,05. Nilai signifikansi tersebut membuktikan hipotesis bahwa motivasi kerja mampu memperkuat pengaruh Good Governance terhadap kinerja pemerintahan. Selain itu, mengenai pembuktian $\mathrm{H} 4 \mathrm{~b}$ ternyata nilai signifikansi dari variabel motivasi kerja yang memoderasi sistem pengendalian intern adalah 0,044 yang artinya lebih kecil dari 0,05 tetapi perlu diperhatikan, bahwa konstanta dari variabel motivasi kerja yang memoderasi sistem pengendalian intern adalah negatif yang dimana berlawanan dengan hipotesis bahwa variabel motivasi kerja yang memoderasi sistem pengendalian intern berpengaruh positif terhadap kinerja. Hal ini berarti bahwa hipotesis motivasi kerja mampu memperkuat pengaruh sistem pengendalian intern terhadap kinerja pemerintahan ditolak. Sedangkan terkait dengan hipotesis $\mathrm{H} 4 \mathrm{c}$, nilai signifikansi dari variabel motivasi kerja yang memoderasi konflik kerja adalah 0,306 yang artinya lebih besar dari 0,05. Nilai signifikansi tersebut berarti 
hipotesis bahwa motivasi kerja mampu memperkuat pengaruh konflik kerja terhadap kinerja pemerintahan ditolak.

Setelah dilaksanakan uji penelitian, hipotesis bahwa variabel Good Governance berpengaruh positif pada kinerja pemerintahan, tidak benar. Good Governance ternyata berpengaruh negatif terhadap kinerja. Hal tersebut dapat terjadi dikarenakan pengimplementasian prinsip-prinsip Good Governance yang tidak dilakukan secara sungguh-sungguh. Pengimplementasian prinsip-prinsip Good Governance yang dilaksanakan secara tidak sungguh-sungguh menghasilkan hal-hal seperti transparansi yang tanggung, tanggung jawab yang masih tumpang tindih, serta kewajaran kerja yang sekedarnya. Hal-hal itu akhirnya hanya akan membuang tenaga serta waktu yang seharusnya dapat digunakan untuk menuntaskan pekerjaan yang bersifat mengejar hasil target kerja. Contoh dari munculnya masalah ini adalah bagaimana pemerintah membuka platform untuk mengungkapkan kegiatan-kegiatan yang sedang diimplementasikan, tetapi transparansi atas kegiatan-kegiatan tersebut tidak dilakukan mengikuti keadaan sebenarnya dan selain itu menyita waktu yang berharga untuk lebih mengerjakan tugas-tugas yang terdapat dalam kantor pemerintahan. Hal tersebut ternyata mendapatkan fakta bahwa teori keagenan tidak mampu mendukung hasil penelitian ini sebelumnya teori keagenan menyatakan bahwa Good Governance dapat memperkuat kinerja.

Mengenai hipotesis yakni variabel sistem pengendalian intern berpengaruh positif pada kinerja pemerintahan, hal tersebut berhasil dibuktikan. Menurut teori keagenan, dalam pelaksanaan kegiatan organisasi, biasanya akan selalu terjadi hambatan-hambatan yang dapat menganggu jalannya organisasi dalam mencapai target yang telah ditetapkan, dan untuk meredam hambatanhambatan tersebut, maka sebuah organisasi memerlukan biaya keagenan. Salah satu biaya keagenan adalah monitoring cost yakni biaya mengarahkan perilaku agen agar agen mampu melaksanakan aktivitas dalam organisasi yang membantu organisasi dalam mencapai tujuannya. Salah satu cara yang dilakukan adalah melaksanakan sebuah sistem pengendalian intern. Hasil Penelitian ini telah sesuai dengan berbagai penelitian sebelumnya seperti yang dilakukan (Ilias et al., 2016) yang berjudul Management Control System and Performance: Accountability Attributes in Local Authorities dan Penelitian dari Putra \& Putra (2018) yang berjudul "Pengaruh Good Governance dan Sistem Pengendalian Intern Pemerintah Pada Kinerja Pemerintah Daerah" yang menunjukkan bahwa sistem pengendalian intern berpengaruh positif pada kinerja.

Hipotesis bahwa variabel konflik kerja berpengaruh positif pada kinerja pemerintahan, tidak benar. Meski konstanta dari konflik kerja berarah positif, tetapi nilai signifikansi dari konflik kerja lebih dari nilai batas signifikansi. Hal ini dikarenakan meski memang konflik kerja berpengaruh positif, tetapi diantara anggota organisasi pemerintahan, terdapat seolah kurang terpacu untuk bersaing meraih prestasi, berubah kearah yang lebih baik serta kurangnya inisiatif untuk melaksanakan kreativitas dalam skala sampai benar-benar mempengaruhi peningkatan kinerja. Hal ini dapat terjadi salah satunya dikarenakan merasa berada pada zona nyaman seperti intensitas pekerjaan yang cenderung rendah atau lingkungan kerja terutama dalam pemerintahan yang terkadang masih belum 
memberi ruang luas untuk kreativitas sehingga menjadi alasan atas fenomena tersebut.

Hipotesis bahwa variabel motivasi kerja mampu memoderasi pengaruh Good Governance pada kinerja pemerintahan, berhasil dibuktikan. Hasil hipotesis ini sesuai dengan Teori ERG dimana dalam teori ini, individu yang berada dalam sebuah organisasi termotivasi untuk memenuhi kebutuhan hidup yang dapat menunjang kualitas hidupnya. Untuk merealisasikan kebutuhan-kebutuhan tersebut, individu dalam pekerjaannya tentu berupaya semaksimal mungkin demi tercapainya tujuan organisasi. Hal tersebut mampu mendorong individu-individu lainnya dalam organisasi untuk bekerja sama dan menjaga kesolidan organisasi. Dengan dilaksanakannya Good Governance dalam organisasi, tujuan organisasi akan lebih mudah diraih. Hasil penelitian ini sesuai dengan penelitian sebelumnya oleh Ruhanda (2018) yang berjudul Pengaruh Kompensasi Dan Penerapan Good Corporate Governance Terhadap Kinerja Pegawai Dengan Motivasi Kerja Sebagai Variabel Intervening Pada Palang Merah Indonesia Kota Bandung yang menunjukkan bahwa Motivasi kerja menguatkan Good Governance.

Mengenai hipotesis bahwa variabel motivasi kerja mampu memoderasi pengaruh sistem pengendalian intern pada kinerja pemerintahan, ternyata hipotesis tersebut gagal dibuktikan. Hal ini dapat terjadi dikarenakan adanya sistem pengendalian intern memberikan sebuah perasaan bahwa anggota dalam organisasi harus melaksanakan kewajibannya sehingga mampu meningkatkan kinerja. Dengan sistem pengendalian intern, pegawai yang yang memiliki motivasi kerja baik tinggi ataupun akan meningkatkan kinerja individunya karena pegawai lebih berorientasi pada kinerja bukan oleh motivasi yang dimilikinya, tetapi karena adanya sistem pengendalian intern pemerintah yang wajib untuk dilaksanakan. Hasil hipotesis ini sesuai dengan penelitian oleh Adhitama \& Gayatri (2017) yang berjudul Pengaruh Sistem Pengendalian Intern Pemerintah, Partisipasi Penyusunan Anggaran Pada Kinerja Individu Dengan Pemoderasi Motivasi Kerja dimana Motivasi tidak mampu memoderasi Sistem Pengendalian Intern.

Mengenai hipotesis bahwa variabel motivasi kerja mampu memoderasi pengaruh konflik kerja pada kinerja pemerintahan, setelah pembuktian, hal trsebut ternyata tidak benar. Signifikansi dari variabel motivasi kerja yang memoderasi pengaruh konflik kerja pada kinerja pemerintahan lebih dari sig 0,05. Konflik kerja dapat terjadi dalam berbagai kegiatan organisasi. Tidak hanya terdapat antara atasan dengan bawahan, anggota yang setingkat, yang rajin ataupun yang malas, siapapun dapat terlibat dalam sebuah konflik kerja dikarenakan konflik kerja sendiri disebabkan oleh berbagai alasan seperti perbedaan pendapat, kritik atas kinerja, serta perbedaan cara kerja. Dan faktorfaktor tersebut tanpa didorong oleh motivasi dapat mengarahkan konflik kerja berkontribusi positif kepada kinerja dengan respon bekerja lebih keras atau menelurkan kreativitas kerja demi meraih target. Sehingga meskipun seseorang memiliki motivasi tinggi ataupun rendah, motivasi tidak dapat memperkuat konflik kerja dikarenakan penyebab-penyebab kemunculan konflik kerja sendiri sudah dapat mendorong seseorang untuk giat meraih target yang telah ditetapkan. 


\section{SIMPULAN}

Kesimpulan yang dapat diambil dari penelitian ini adalah bahwa pelaksanaan penerapan sistem pengendalian internal yang memadai seperti evaluasi kinerja berkala yang lebih intensif, tetapi tentunya tidak sampai menimbulkan ketidaknyamanan kerja pegawai di dalam organisasi perangkat daerah serta membangkitkan motivasi kerja para pegawai seperti meningkatkan berbagai insentif seperti gaji, pujian, penghargaan, dan sebagainya secara menyeluruh mampu berkontribusi banyak dalam meningkatkan kinerja pemerintahan sehingga mencapai atau bahkan melampaui target hasil kerja pemerintahan.

\section{REFERENSI}

Adhitama, P. I., \& Gayatri. (2017). Pengaruh Sistem Pengendalian Intern Pemerintah, Partisipasi Penyusunan Anggaran Pada Kinerja Individu Dengan Pemoderasi Motivasi Kerja. Jurnal Akuntansi Universitas Udayana, 19(3), 2556-2585.

Afiah, N. N., \& Azwari, P. C. (2015). The Effect of the Implementation of Government Internal Control System (GICS) on the Quality of Financial Reporting of the Local Government and its Impact on the Principles of Good Governance: A Research in District, City, and Provincial Government in South Sumatera. Procedia - Social and Behavioral Sciences, 211, 811-818.

Aziz, M. A. A., Rahman, H. A., Alam, M. M., \& Said, J. (2015). Enhancement of the Accountability of Public Sectors through Integrity System, Internal Control System and Leadership Practices: A Review Study. Procedia Economics and Finance, 28, 163-169.

Azlina, N., \& Amelia, I. (2014). Pengaruh Good Governance Dan Pengendalian Intern Terhadap Kinerja Pemerintah Kabupaten Pelalawan. Jurnal Akuntansi Universitas Jember, 12(2), 32-42.

Chatzopoulou, M., Vlachvei, A., \& Monovasilis, T. (2015). Employee's Motivation and Satisfaction in Light of Economic Recession: Evidence of Grevena Prefecture-Greece. Procedia Economics and Finance, 24, 136-145.

Ciobanu, A., \& Androniceanu, A. (2015). Civil Servants Motivation and Work Performance in Romanian Public Institutions. Procedia Economics and Finance, 30, 164-174.

Endila, V., \& Syamsir. (2017). Pengaruh Konflik Kerja Terhadap Kinerja Perangkat Nagari Dalam Pengelolaan Keuangan Nagari di Kabupaten 50 Kota. Jurnal Administrasi Negara, Maret, 5(1), 11-20.

Fatikhin, F., Hamid, D., \& Mukzam, M. D. (2017). Pengaruh Konflik Kerja Dan Stres Kerja Terhadap Kinerja Karyawan (Studi pada Karyawan PT. Bank Rakyat Indonesia (Persero) Cabang Soekarno Hatta Malang). In Jurnal Administrasi Bisnis (JAB), 47(1), 172-180

Ghozali, H. I. (2016). Aplikasi Analisis Multivariate dengan Program IMB SPSS 23. Edisi Kedelapan. Universitas Diponegoro.

Hokayem, J. El, \& Kairouz, A. (2014). Euro-med: Public Management and Good Local Governance. Procedia - Social and Behavioral Sciences, 124, 528-535.

Ilias, N., Kamaruzaman Abdulatiff, N., \& Mohamed, N. (2016). International Journal of Economics and Financial Issues Management Control System and Performance: Accountability Attributes in Local Authorities. International 
Journal of Economics and Financial Issues, 6(S4), 26-35.

Julianry, A., Syarief, R., \& Affandi, M. J. (2017). Pengaruh Pelatihan dan Motivasi Terhadap Kinerja Karyawan serta Kinerja Organisasi Kementerian Komunikasi dan Informatika. Jurnal Aplikasi Bisnis Dan Manajemen, 3(2), 236245.

Khoshnevis, H., \& Tahmasebi, A. (2016). The Motivation System in a Governmental Organization. Procedia - Social and Behavioral Sciences, 230, 212218.

Lee, M. T., \& Raschke, R. L. (2016). Understanding employee motivation and organizational performance: Arguments for a set-theoretic approach. Journal of Innovation and Knowledge, 1(3), 162-169.

Mayvita, S. A., Astuti, E. S., \& Ruhana, I. (2017). Pengaruh Motivasi Existence, Relationship, Growth (ERG) Terhadap Prestasi Kerja (Studi Pada Karyawan PT. PLN (Persero) Unit Induk Pembangunan Jawa Bagian Timur dan Bali II). In Jurnal Administrasi Bisnis (JAB), 47(2), 168-176.

Naz'aina. (2015). The Effect of Internal Control System and Amil Competence on the Financial Reporting Quality at Zakat Management Institution Active Member of Zakat Forum in Special Capital City Region Jakarta and West Java Provinces. Procedia - Social and Behavioral Sciences, 211, 753-760.

Pemerintah Kabupaten Klungkung. (2020). Laporan Kinerja Instansi Pemerintah Kabupaten Klungkung Tahun 2019.

Purwanto, W. (2015). Analysis of the Impact of Good Corporate Governance and Bank Fundamentals to the Financial Performance of Banking Institutions in the Indonesian Stock Exchange (BEI). Research Journal of Finance and Accounting, 6(8), 1-6

Putra, I. G. A. S., \& Dwiana Putra, I. M. P. (2018). Pengaruh Good Governance dan Sistem Pengendalian Intern Pemerintah Pada Kinerja Pemerintah Daerah. EJurnal Akuntansi, 25(3), 1720 - 1743

Ruhanda. (2018). Pengaruh Kompensasi Dan Penerapan Good Corporate Governance Terhadap Kinerja Pegawai Dengan Motivasi Kerja Sebagai Variabel Intervening Pada Palang Merah Indonesia Kota Bandung. Jurnal Maps (Manajemen Perbankan Syariah), 2(1), 10-20.

Santosa, I., Sumber, D., Air, D., Banten, P.-P., Ismaya, A., Sultan, U., \& Tirtayasa, A. (2017). Pengaruh Struktur Pengendalian Internal dan Budaya Organisasi terhadap Kinerja Pegawai. Jurnal Riset Akuntansi Tirtayasa, 2(1), 47-83.

Sanusi, Z. M., Johari, R. J., Said, J., \& Iskandar, T. (2015). The Effects of Internal Control System, Financial Management and Accountability of NPOs: The Perspective of Mosques in Malaysia. Procedia Economics and Finance, 28, 156162.

Sugiyono. (2017). Metode Penelitian Bisnis. CV Alfabeta.

Taghipour, A., \& Dejban, R. (2013). Job Performance: Mediate Mechanism of Work Motivation. Procedia - Social and Behavioral Sciences, 84, 1601-1605.

Valentina, J., Suseno, Y. D., \& Widajanti, E. (2020). Pengaruh Burnout Dan Konflik Kerja Terhadap Kinerja Dengan Motivasi Kerja Sebagai Variabel Moderasi Pada Perawat RSUD Dr Moewardi Surakarta. Jurnal Manajemen SumberDaya Manusia, 14, 132-142.

van der Kolk, B., van Veen-Dirks, P. M. G., \& ter Bogt, H. J. (2019). The Impact of 
Management Control on Employee Motivation and Performance in the Public Sector. European Accounting Review, 28(5), 901-928.

Widasari, K. I., \& Dwija Putri, I. G. A. M. A. (2018). Pengaruh Good Governance dan Budaya Organisasi Terhadap Kinerja Manajerial Penyelenggara Pemerintahan Desa di Kabupaten Badung. E-Jurnal Akuntansi, 22(2), 13081334.

Wijaya, W. A., Arifati, R., \& Suprijanto, A. (2016). Analisis Pengaruh Independensi, Motivasi, Pengalaman Kerja, Profesionalisme, Dan Gaya Kepemimpinan Terhadap Efektivitas Penerapan Sistem Pengendalian Intern. Jurnal Akuntansi Universitas Pandanaran Semarang, 2(2), 1-19.

Yofandi, A. (2017). Pengaruh Konflik Kerja, Stres Kerja, Dan Semangat Kerja Terhadap Kinerja Karyawan Padapt. Perkebunan Nusantara V (Persero) Pekanbaru. Jurnal Fakultas Ekonomi Dan Bisnis Universitas Riau, 4(1), 10151029.

Yudhasena, I. G. I., \& Putri, I. G. A. M. Asri Dwija. (2019). Pengaruh Good Government Governance, Pengendalian Intern, dan Budaya Organisasi Terhadap Kinerja Organisasi Perangkat Daerah (OPD). E-Jurnal Akuntansi, 28(1), 434-464.

Yurniwati, \& Rizaldi, A. (2015). Control Environment Analysis at Government Internal Control System: Indonesia Case. Procedia - Social and Behavioral Sciences, 211, 844-850.

Zogning, F. (2017). Agency Theory: A Critical Review. In European Journal of Business and Management. 9(2), 1-8 